\title{
Magnesium bioavailability from mineral waters with different mineralization levels in comparison to bread and a supplement
}

\author{
Inga Schneider, Theresa Greupner and Andreas Hahn \\ Institute of Food Science and Human Nutrition, Leibniz University Hannover, Hannover, Germany
}

\begin{abstract}
The aim of the present study was to compare the magnesium bioavailability from four mineral waters with different types of mineralization (e.g. $\mathrm{SO}_{4}{ }^{2-}, \mathrm{HCO}_{3}{ }^{-}$, calcium) with the magnesium bioavailability from bread and from a magnesium supplement. A single-center, randomized, controlled trial with a crossover design with 22 healthy men and women was conducted at the Institute of Food Science and Human Nutrition, Leibniz University Hannover, Germany. The participants consumed the six test products providing $100 \mathrm{mg}$ of magnesium each on six examination days with a one-week washout phase in between. The primary outcome variables were the $24 \mathrm{~h}$ urinary magnesium excretion, the $24 \mathrm{~h}$ urinary magnesium/creatinine ratio, and the area under the curve of serum magnesium levels for $10 \mathrm{~h}\left(\mathrm{AUC}_{0-10 \mathrm{~h}}\right)$. No significant differences among groups were observed for either $24 \mathrm{~h}$ urinary magnesium excretion or $24 \mathrm{~h}$ urinary magnesium/ creatinine ratio. Likewise, statistical group comparisons of $A U C_{0-10 \mathrm{~h}}$ for serum magnesium levels revealed no significant differences among the treatment groups. Accordingly, given equivalent magnesium availability from all test products, neither $\mathrm{SO}_{4}{ }^{2-}$ content nor the content of $\mathrm{HCO}_{3}{ }^{-}$or of calcium influenced the bioavailability of magnesium. Thus, mineral water with higher concentrations of magnesium constitutes a calorie-free magnesium source that contributes to optimal magnesium supply.
\end{abstract}

\section{ARTICLE HISTORY}

Received 17 July 2017

Accepted 21 September 2017

\section{KEYWORDS}

Mineral water; magnesium; bioavailability; mineralization; general nutrition

\section{Introduction}

Magnesium ( $\mathrm{Mg})$ is the second most abundant intracellular cation after potassium and the fourth most abundant cation in the human body. This essential mineral is required for a broad range of physiological and biochemical functions. As a cofactor in more than 300 enzymatic reactions, many of which are dependent on ATP, Mg is involved in many key biochemical pathways, including pathways related to macronutrient degradation, oxidative phosphorylation, DNA and protein synthesis, neuromuscular excitability, and the regulation of parathyroid hormone secretion [1-4].

Furthermore, a low Mg intake may increase the risk of depression [5]. Moreover, children with diabetes mellitus have significantly lower Mg levels than in healthy controls [6]. Mg homeostasis depends on Mg intake but is mostly determined by the renal excretion of $\mathrm{Mg}$ [7]. Current recommendations for $\mathrm{Mg}$ for adults vary from $400-420 \mathrm{mg} / \mathrm{d}$ for men and $310-320 \mathrm{mg} / \mathrm{d}$ for women in the US (recommended daily allowance, RDA) to $350 \mathrm{mg} / \mathrm{d}$ for men and $300 \mathrm{mg} / \mathrm{d}$ for women in the EU (adequate intake, $\mathrm{AI}$ ), and $300 \mathrm{mg} / \mathrm{d}$ for men and
$270 \mathrm{mg} / \mathrm{d}$ for women in the UK (reference nutrient intake, RNI) [8-11]. When usual Mg consumption patterns were analyzed, most population groups consumed less than the RDA. Data from the National Health and Nutrition Examination Survey (NHANES) indicate that in the US $48 \%$ of adult males and $46 \%$ of adult females do not meet the current dietary recommendation for $\mathrm{Mg}$ [12]. However, in Germany Mg is the most supplemented mineral with $59.4 \%$, followed by calcium with $37.0 \%$ [13].

Nuts, green leafy vegetables, and whole grains are relatively rich sources of dietary $\mathrm{Mg}$. Nevertheless, these foods only contribute a maximum of approximately $10 \%$ of the recommended intake of $\mathrm{Mg}$ [14]. According to the second German National Nutrition Survey (NVS II), men and women consume the largest proportion of magnesium over bread after alcohol-free beverages [15]. Certainly, wholemeal bread contains considerable amounts of phytic acid, which lowers the bioavailability of minerals, including iron, zinc, calcium, and $\mathrm{Mg}$ [16]. Given the low content of $\mathrm{Mg}$ in most foods and the phytic acid content of wholemeal bread, alternative sources of $\mathrm{Mg}$ should be preferred.

CONTACT Inga Schneider schneider@nutrition.uni-hannover.de $\Theta$ Institute of Food Science and Human Nutrition, Leibniz University of Hannover, Am Kleinen Felde 30, 30167 Hannover, Germany.

(c) 2017 The Author(s). Published by Informa UK Limited, trading as Taylor \& Francis Group.

This is an Open Access article distributed under the terms of the Creative Commons Attribution License (http://creativecommons.org/licenses/by/4.0/), which permits unrestricted use, distribution, and reproduction in any medium, provided the original work is properly cited. 
Mineral water (MW) is a promising candidate because it is calorie-free, contains no potential allergens, and ensures hydration. Furthermore, although the Mg content of mineral waters varies widely depending on the water source, it can reach more than $150 \mathrm{mg} / \mathrm{l}$ [17].

According to the literature, $\mathrm{Mg}$ from mineral water and supplements is bioavailable [17-22]. However, it is unknown whether $\mathrm{Mg}$ bioavailability from mineral water is comparable to $\mathrm{Mg}$ bioavailability from bread. Furthermore, $\mathrm{Mg}$ bioavailability from mineral water may be influenced by concentrations of other minerals, such as calcium, in the water $[23,24]$. Therefore, the aim of the present study was to compare the $\mathrm{Mg}$ bioavailability from four mineral waters with different types of mineralization with $\mathrm{Mg}$ bioavailability from bread and from a Mg supplement.

\section{Materials and methods}

\section{Study design}

A single-center, randomized, controlled trial with a crossover design was conducted by trained professionals using standardized methods at the Institute of Food Science and Human Nutrition, Leibniz University Hannover, Germany. The study involved a screening phase and six examinations with a one-week washout phase prior to each examination.

Ethical approval was provided by the Ethics Commission of the Medical Chamber of Lower Saxony (Hannover, Germany). In accordance with the guidelines of the Declaration of Helsinki, written informed consent was obtained from all subjects prior to their participation in the study. This study is registered in the German Clinical Trial Register (DRKS00010411).

\section{Subjects}

Healthy participants were recruited via advertisements from the general population in Hannover, Germany. They were selected according to inclusion and exclusion criteria, which were assessed using questionnaires. The main inclusion criteria were an age between 18 and 50 years and a body mass index (BMI) between
18.5 and $29.9 \mathrm{~kg} / \mathrm{m}^{2}$. The exclusion criteria were an allergy to any of the test products, the intake of $\mathrm{Mg}$ supplements, the regular intake of laxatives, and chronic gastrointestinal disorders or prior gastrointestinal surgical procedures.

\section{Test products and procedure}

Four different mineral waters (MW 1, MW 2, MW 3, and MW 4), whole rye bread, and a supplement containing magnesium carbonate $\left(\mathrm{MgCO}_{3}\right)$ were investigated in this bioavailability study. The mineral concentrations of the six test products are indicated in Table 1. Procedure has already been described in Greupner et al. [25]. In brief, test products were adjusted to provide $100 \mathrm{mg}$ of $\mathrm{Mg}$, with the exception of the $\mathrm{Mg}$ supplement, which contained $110 \mathrm{mg}$ of $\mathrm{Mg}$ per tablet. As needed, product volumes were reached via the addition of demineralized water to ensure the consumption of equal quantities of fluids across all groups. All participants received each test product in an individually randomized order generated in a Williams design.

Participants were instructed to minimize their $\mathrm{Mg}$ intake two days before each examination and to avoid excessive exercise on the day prior to the examination. A list of restricted foods was given to each participant prior to the intervention.

On the examination days, each participant consumed one of the test products in a randomized order after an overnight fast. Participants were instructed to drink $\mathrm{Mg}$-poor water (8 $\mathrm{mg}$ of $\mathrm{Mg}$ per liter) at defined time points during the $12 \mathrm{~h}$ preceding the first draw of fasting blood. Test products had to be consumed within 30 minutes and were given with a standardized breakfast $(9.8 \mathrm{mg}$ $\mathrm{Mg} /$ portion). Blood samples were drawn initially and at $1,2,3,4,5,6,8$, and $10 \mathrm{~h}$ after the intake of the test product. Urine samples were collected pre-dose and at defined intervals up to $24 \mathrm{~h}$ after dosing $(0-2,2-4,4-6,6-8,8-12$, and $12-24 \mathrm{~h})$. During the experimental period $(24 \mathrm{~h})$, the participants consumed standardized Mg-poor meals and water. The total $\mathrm{Mg}$ intake from the background

Table 1. Mineral composition of the six test products (MW 1: mineral water 1; MW 2: mineral water 2; MW 3: mineral water 3; MW 4: mineral water 4; Suppl.: magnesium supplement) .

\begin{tabular}{|c|c|c|c|c|c|c|}
\hline Mineral value & MW 1 & MW 2 & MW 3 & MW 4 & Bread $^{a}$ & Suppl. $^{\text {b }}$ \\
\hline $\mathrm{Mg}^{2+}$ & $241 \mathrm{mg} / \mathrm{l}$ & $108 \mathrm{mg} / \mathrm{l}$ & $124 \mathrm{mg} / \mathrm{l}$ & $137 \mathrm{mg} / \mathrm{l}$ & $531 \mathrm{mg} / \mathrm{kg}$ & $110 \mathrm{mg} /$ pill \\
\hline $\mathrm{Ca}^{2+}$ & $168 \mathrm{mg} / \mathrm{l}$ & $348 \mathrm{mg} / \mathrm{l}$ & $528 \mathrm{mg} / \mathrm{l}$ & $290 \mathrm{mg} / \mathrm{l}$ & n.a. & - \\
\hline $\mathrm{Na}^{+}$ & $261 \mathrm{mg} / \mathrm{l}$ & $118 \mathrm{mg} / \mathrm{l}$ & $28.8 \mathrm{mg} / \mathrm{l}$ & $100 \mathrm{mg} / \mathrm{l}$ & n.a. & - \\
\hline $\mathrm{Cl}^{-}$ & 14 mg/l & $40 \mathrm{mg} / \mathrm{l}$ & $28.9 \mathrm{mg} / \mathrm{l}$ & $181 \mathrm{mg} / \mathrm{l}$ & n.a. & - \\
\hline $\mathrm{SO}_{4}^{2-}$ & $17 \mathrm{mg} / \mathrm{l}$ & $38 \mathrm{mg} / \mathrm{l}$ & $1463 \mathrm{mg} / \mathrm{l}$ & $8.8 \mathrm{mg} / \mathrm{l}$ & n.a. & - \\
\hline $\mathrm{HCO}_{3}{ }^{-}$ & $2451 \mathrm{mg} / \mathrm{l}$ & 1816 mg/l & $403 \mathrm{mg} / \mathrm{l}$ & $1519 \mathrm{mg} / \mathrm{l}$ & n.a. & - \\
\hline
\end{tabular}

n.a.: not analyzed; ${ }^{a}$ whole rye; ${ }^{\mathrm{b}}$ magnesium carbonate $\left(\mathrm{MgCO}_{3}\right)$ 
diet was $195.2 \mathrm{mg}$. Additionally, the participants consumed $100 \mathrm{mg}$ from the test products (MW 1, MW 2, MW 3, MW 4, and bread) or $110 \mathrm{mg}$ from the $\mathrm{Mg}$ supplement. After the $10 \mathrm{~h}$ blood draw, the participants were allowed to drink $\mathrm{Mg}$-poor water at any time, in quantities not exceeding 1 liter.

The primary outcome variables were the $24 \mathrm{~h}$ urinary $\mathrm{Mg}$ excretion, the $24 \mathrm{~h}$ urinary $\mathrm{Mg} /$ creatinine excretion ratio, and area under the curve for serum $\mathrm{Mg}$ levels for $10 \mathrm{~h}\left(\mathrm{AUC}_{0-10 \mathrm{~h}}\right)$. Urinary excretion of $\mathrm{Mg}$ and serum concentrations of $\mathrm{Mg}$ were examined as secondary outcome variables. The blood and the urine samples were prepared and analyzed by the Hannover Medical Care Center of the LADR network. The blood sample quantities were $10.2 \mathrm{ml}$ of the fasting sample and $2.4 \mathrm{ml}$ of each following sample, which results in a total blood volume of $29.4 \mathrm{ml}$ per day. The urine sample quantities were $1 \mathrm{ml}$ of the fasting sample and $10 \mathrm{ml}$ of the $24 \mathrm{~h}$ urine sample. The detection limits and coefficients of variation $(\mathrm{CV})$ for the measurements were $0.02 \mathrm{mmol} / \mathrm{l}(2.73 \mathrm{CV} \%)$ for urinary $\mathrm{Mg}, 0.01 \mathrm{mmol} / \mathrm{l}(1.15 \mathrm{CV} \%)$ for serum $\mathrm{Mg}$, and $0.1 \mu \mathrm{mol} / 1(1.31 \mathrm{CV} \%)$ for urinary creatinine.

\section{Data analysis and statistical methods}

Data are presented as the means \pm standard deviation (SD) for continuous variables. All serum levels were corrected using their respective baseline levels. $\mathrm{AUC}_{0-}$ $10 \mathrm{~h}$ for serum $\mathrm{Mg}$ levels were calculated geometrically using the trapezoidal rule, ignoring the area below the baseline. If the Kolmogorov-Smirnov test indicated that the study data were not normally distributed, log transformation was applied, and parametric tests were used. Differences among urinary $\mathrm{Mg}$ excretion, urinary $\mathrm{Mg} /$ creatinine ratio, and $\mathrm{AUC}_{0-10 \mathrm{~h}}$ for serum Mg levels were analyzed using ANOVA for repeated measurements. Mauchly's test was used to determine sphericity. When sphericity could not be assumed, the Greenhouse-Geisser correction was applied. Values of $\mathrm{p} \leq 0.05$ were regarded as statistically significant. All statistical analyses were performed using SPSS software (version 23.0; SPSS Inc., Chicago, IL, USA).

\section{Results}

\section{Study population}

Twenty-two healthy males and females (men: $\mathrm{n}=11$, women: $\mathrm{n}=11$ ) participated in the study. The subjects' mean age was $24.2 \pm 3.2$ years and their mean BMI was $23.6 \pm 2.4 \mathrm{~kg} / \mathrm{m}^{2}$.

\section{Serum and urinary concentrations of magnesium and creatinine}

No significant differences among groups were observed for either $24 \mathrm{~h}$ urinary $\mathrm{Mg}$ excretion or $24 \mathrm{~h}$ urinary $\mathrm{Mg} /$ creatinine ratio. Likewise, statistical group comparisons of $\mathrm{AUC}_{0-10 \mathrm{~h}}$ for serum $\mathrm{Mg}$ levels revealed no significant differences among the treatment groups (Table 2). Urinary Mg excretion was initially high and continuously decreased over the following $2 \mathrm{~h}$ in all groups. In nearly all groups, after an initial increase, serum $\mathrm{Mg}$ levels remained nearly constant after $2 \mathrm{~h}$. Serum $\mathrm{Mg}$ levels also increased after consumption of the supplement but fluctuated after $2 \mathrm{~h}$, with no decreases observed (Figure 1).

\section{Discussion}

The present crossover study, sought to compare the $\mathrm{Mg}$ bioavailability from four mineral waters with different types of mineralization with the $\mathrm{Mg}$ bioavailability from a $\mathrm{Mg}$ supplement, and (assumed for the first time) from bread. In general, $\mathrm{Mg}$ was bioavailable from all test products. This finding is consistent with the results of prior studies that revealed Mg bioavailability from mineral water and dietary supplements [17-20,26]. Urinary $\mathrm{Mg}$ excretion increased after the consumption of all test products, and $24 \mathrm{~h}$ urinary $\mathrm{Mg}$ excretion did not significantly differ among the test products. This result is consistent with findings from

Table 2. Twenty-four hours of urinary magnesium excretion, $24 \mathrm{~h}$ urinary magnesium/creatinine ratio, and area under the curve (AUC0-10h) for serum magnesium levels for $10 \mathrm{~h}$ (mean $\pm \mathrm{SD}$ ).

\begin{tabular}{|c|c|c|c|c|c|c|}
\hline \multirow[b]{2}{*}{ MW 1} & \multicolumn{2}{|c|}{$24 \mathrm{~h}$ urinary $\mathrm{Mg}$ excretion [mmol] } & \multicolumn{2}{|c|}{$24 \mathrm{~h}$ urinary $\mathrm{Mg} / \mathrm{creatinine}$ ratio [mmol] } & \multicolumn{2}{|c|}{$\mathrm{AUC}_{0-10 \mathrm{~h}}$ serum $\mathrm{Mg}$} \\
\hline & $4.41 \pm 1.50$ & $n=22$ & $0.55 \pm 0.79$ & $\mathrm{n}=18$ & $0.80 \pm 0.35$ & $\mathrm{n}=22$ \\
\hline MW 2 & $4.47 \pm 1.17$ & $\mathrm{n}=20$ & $0.43 \pm 0.15$ & $\mathrm{n}=18$ & $0.89 \pm 0.40$ & $\mathrm{n}=21$ \\
\hline MW 3 & $4.41 \pm 1.58$ & $\mathrm{n}=22$ & $0.40 \pm 0.08$ & $\mathrm{n}=18$ & $0.78 \pm 0.37$ & $\mathrm{n}=22$ \\
\hline MW 4 & $4.68 \pm 1.44$ & $\mathrm{n}=21$ & $0.71 \pm 1.36$ & $\mathrm{n}=18$ & $0.99 \pm 0.39$ & $\mathrm{n}=21$ \\
\hline Bread & $4.12 \pm 1.74$ & $\mathrm{n}=22$ & $0.34 \pm 0.07$ & $\mathrm{n}=18$ & $0.81 \pm 0.31$ & $\mathrm{n}=22$ \\
\hline $\begin{array}{l}\text { Suppl. } \\
\text { p }\end{array}$ & $\begin{array}{c}4.21 \pm 1.53 \\
0.194^{2}\end{array}$ & $n=21$ & $\begin{array}{c}0.35 \pm 0.07 \\
0.382^{\mathrm{a}}\end{array}$ & $n=18$ & $\begin{array}{c}0.82 \pm 0.32 \\
0.401^{\mathrm{a}}\end{array}$ & $n=22$ \\
\hline
\end{tabular}

a sphericity given

b Greenhouse-Geisser correction 

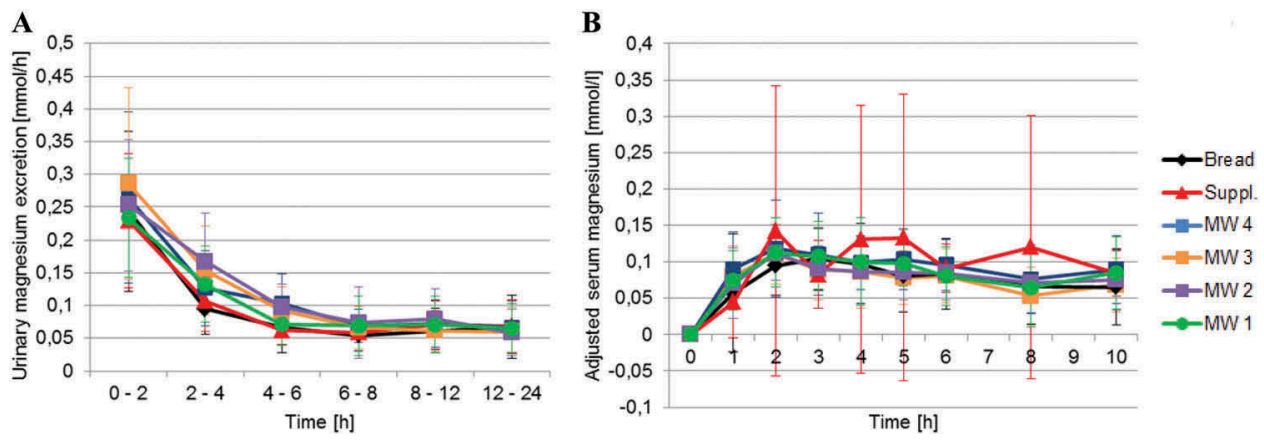

Figure 1. Mean \pm SD urinary magnesium excretion ( $A$; MW 1: $n=22, M W 2: n=20, M W 3: n=22, M W 4: n=21$, Bread: $n=21$, Suppl.: $n=22)$ and mean \pm SD serum magnesium concentrations corrected to baseline $(B ; M W 1: n=22, M W 2: n=21, M W 3$ : $\mathrm{n}=22$, MW 4: $\mathrm{n}=21$, Bread: $\mathrm{n}=22$, Suppl.: $\mathrm{n}=22$ ) after consumption of the test products.

previous studies that reveal comparable urinary $\mathrm{Mg}$ excretion after the intake of mineral water, standard meals, and dietary supplements [17,22,27]. In addition, no significant differences among the test products were found with respect to the $\mathrm{Mg} /$ creatinine ratio. The $\mathrm{Mg} /$ creatinine ratio reveals to possible bias due to incomplete urine collection. Furthermore, a normal urinary $\mathrm{Mg} /$ creatinine ratio indicates normal urinary $\mathrm{Mg}$ excretion and adequate $\mathrm{Mg}$ intake [28,29]. Our finding of normal $\mathrm{Mg} /$ creatinine ratios implies that there was complete urine collection and adequate $\mathrm{Mg}$ intake for all subjects. Furthermore, the intake of $100 \mathrm{mg}$ of $\mathrm{Mg}$ from each product revealed no significant differences among the test products with respect to $\mathrm{AUC}_{0-10 \mathrm{~h}}$ for serum Mg. Thus, the different mineralization levels of the tested mineral waters did not affect $\mathrm{Mg}$ bioavailability.

$\mathrm{Mg}$ homeostasis is strictly regulated by urinary excretion and urinary retention [7]. Thus, subjects with low initial serum Mg levels, suggesting a severe tissue $\mathrm{Mg}$ deficiency, have remarkably elevated urinary $\mathrm{Mg}$ retention [20]. In this study, the fasting Mg levels of all participants were within the normal range. Furthermore, prior studies have suggested an agerelated decline in the capacity of the intestine to absorb dietary Mg [30,31]. This suggestion was supported by an experimental study that assesses enteral $\mathrm{Mg}$ absorption from a magnesium-rich mineral water and revealed a significant inverse correlation between age and $\mathrm{Mg}$ absorption [21]. However, this potential effect could be excluded in the present study due to the homogenous nature of the study population (mean age $24.2 \pm 3.2$ years). Furthermore, correlation analyses of the $\mathrm{AUC}_{0-10 \mathrm{~h}}$ for serum $\mathrm{Mg}$ as well as the $24 \mathrm{~h}$ urinary $\mathrm{Mg}$ excretion and the age have not shown significant correlations between the parameters.

Mg bioavailability may be affected by formulationrelated influences. Studies comparing solutions with capsules or enteric coated tablet formulations have found comparable $\mathrm{Mg}$ absorption for these products. However, increases in serum $\mathrm{Mg}$ levels were delayed after the consumption of enteric coated tablets $[17,32]$. Moreover, the formulation of a $\mathrm{Mg}$ supplement can affect urinary $\mathrm{Mg}$ excretion. Siener et al. showed that urinary $\mathrm{Mg}$ excretion increased by $40 \%$ after the ingestion of an effervescent tablet but by only $20 \%$ after the intake of a capsule [33]. However, in the present study, there was no difference in $\mathrm{Mg}$ absorption between the $\mathrm{Mg}$ supplement and the other test products.

The main finding of this study relates to the effect of different types of mineralization of mineral waters on the bioavailability of Mg. Notably, MW 3 was rich in $\mathrm{SO}_{4}{ }^{2-}(1463 \mathrm{mg} / \mathrm{l})$, which is thought to potentially increase urinary volume and therefore decrease $\mathrm{Mg}$ bioavailability $[34,35]$. To our knowledge, no study has investigated the potential influence of $\mathrm{SO}_{4}{ }^{2-}$ in food on the bioavailability of $\mathrm{Mg}$ in humans. Additionally, MW 3 was low in $\mathrm{HCO}_{3}{ }^{-}(403 \mathrm{mg} / \mathrm{l})$ compared with MW 1 (2451 mg/l), MW 2 (1816 mg/ 1), and MW $4(1519 \mathrm{mg} / \mathrm{l})$. To date, no study has determined the effect of $\mathrm{HCO}_{3}{ }^{-}$on $\mathrm{Mg}$ bioavailability. Mineral water with higher concentration of calcium causes a significant increase in the urinary magnesium concentration [36]. However, correlation analysis of the $24 \mathrm{~h}$ urinary $\mathrm{Mg}$ excretion and the calcium content of mineral water has not shown a significant correlation between the parameters. Likewise, the Mg bioavailability was not influenced by different calcium concentrations in the tested mineral waters. $\mathrm{Mg}$ bioavailabilities were comparable and did not significantly differ for the products tested in this study. Therefore, neither $\mathrm{SO}_{4}{ }^{2-}$ content nor the content of $\mathrm{HCO}_{3}{ }^{-}$or calcium influenced the bioavailability of $\mathrm{Mg}$.

The current study had certain limitations. Participants received only a single dose of $\mathrm{Mg}$ from 
each of the test products. However, the efficiency of $\mathrm{Mg}$ absorption and retention (and therefore Mg bioavailability) can be enhanced by equally distributing $\mathrm{Mg}$ intake into smaller quantities over the course of a day. This increase might be due to the absorption of low quantities of $\mathrm{Mg}$ via transient receptor potential ion channels. Accordingly, distribution of $\mathrm{Mg}$ ingestion over a day could prevent saturation of these channels. In addition, the large volume of water consumed with the single bolus of test products may have decreased the transit time of $\mathrm{Mg}$ in the intestine. Therefore, total $\mathrm{Mg}$ uptake could have been limited by reduced exposure time $[19,22]$. These effects should be investigated in greater depth and considered in future trials.

\section{Conclusion}

The results of serum and urine analysis indicated that $\mathrm{Mg}$ bioavailability was comparable for mineral waters with different mineralization levels, bread, and a dietary supplement. Specifically, $\mathrm{Mg}$ bioavailability was not influenced by the presence of $\mathrm{SO}_{4}{ }^{2-}, \mathrm{HCO}_{3},{ }^{-}$or calcium. Thus, mineral water with higher concentrations of $\mathrm{Mg}$ constitutes a calorie-free $\mathrm{Mg}$ source that contributes to optimal Mg supply. Future studies should be conducted to examine typical consumption patterns for mineral water because multiple portions consumed throughout the day may increase $\mathrm{Mg}$ bioavailability. Additional, the results of forthcoming intervention studies should complement the present findings by establishing the effect of mineral water with high $\mathrm{Mg}$ concentrations on cardiovascular risk factors.

\section{Acknowledgments}

The authors would like to thank all of the subjects who took part in this study.

\section{Disclosure statement}

Study realization, data analysis, and reporting were undertaken independently from the sponsor. The supplement was provided by Dr. Paul Lohmann GmbH KG, Emmerthal/Germany. The authors declare no potential conflicts of interest.

\section{Funding}

This study was sponsored by the Association of German Mineral Bottlers (VDM), Bonn, Germany.

\section{References}

[1] Ranade VV, Somberg JC. Bioavailability and pharmacokinetics of magnesium after administration of magnesium salts to humans. Am J Ther. 2001;8:345-357.

[2] Wolf FI, Trapani V. Cell (patho)physiology of magnesium. Clin Sci. 2008;114:27-35.

[3] Whang R, Hampton EM, Whang DD. Magnesium homeostasis and clinical disorders of magnesium deficiency. Ann Pharmacother. 1994;28:220-226.

[4] Ayuk J, Gittoes NJL. Treatment of hypomagnesemia. Am J Kidney Dis Off J Natl Kidney Found. 2014;63:691-695.

[5] Serefko A, Szopa A, Wlaź P, et al. Magnesium in depression. Pharmacol Rep PR. 2013;65:547-554.

[6] Bjelakovic G, Sokolovic D, Ljiljana S, et al. Arginase activity and magnesium levels in blood of children with diabetes mellitus. J Basic Clin Physiol Pharmacol. 2009;20:319-334.

[7] Wolf MTF. Inherited and acquired disorders of magnesium homeostasis. Curr Opin Pediatr. 2016;29:187-198.

[8] Deutsche Gesellschaft für Ernährung (DGE), Österreichische Gesellschaft für Ernährung (ÖGE), Schweizerische Gesellschaft für Ernährung (SGE),, editor. Referenzwerte für die Nährstoffzufuhr. Bonn: DGE; 2016.

[9] EFSA. European Food Safety Authority (EFSA) panel on dietetic products, nutrition and allergies (NDA). Scientific opinion on dietary reference values for magnesium: dietary reference values for magnesium. EFSA J. 2015;13:4186.

[10] Rayman M, Callaghan A. Appendix 3: table of UK and USA dietary reference values for vitamins, minerals and trace elements. Nutr Arthritis [Internet]. 2006:235-236. Blackwell Publishing Ltd. doi:10.1002/9780470775011. app3/summary

[11] Institute of Medicine (U.S.), editor. Dietary reference intakes: for calcium, phosphorus, magnesium, vitamin $\mathrm{D}$, and fluoride. Washington (DC): National Academy Press; 1997

[12] Deng X, Song Y, Manson JE, et al. Magnesium, vitamin D status and mortality: results from US National Health and Nutrition Examination Survey (NHANES) 2001 to 2006 and NHANES III. BMC Med. 2013;11:187.

[13] Willers J, Heinemann M, Bitterlich N, et al. Intake of minerals from food supplements in a german population-a nationwide survey. Food Nutr Sci. 2015;06:205.

[14] Guerrera MP, Volpe SL, Mao JJ. Therapeutic uses of magnesium. Am Fam Physician. 2009;80:157-162.

[15] Max-Rubner-Institut. Ergebnisbericht Teil 2, Nationale Verzehrsstudie II. Lebensm.-Warenkd. Für Einsteig. [Internet]. Springer;2008. p. 121-148. doi:10.1007/9783-662-46280-5_6

[16] Lopez HW, Leenhardt F, Remesy C. New data on the bioavailability of bread magnesium. Magnes Res. 2004; 17:335-340.

[17] Karagülle O, Kleczka T, Vidal C, et al. Magnesium absorption from mineral waters of different magnesium content in healthy subjects. Forsch Komplementärmedizin Res Complemen Med. 2006;13:9-14. 
[18] Sabatier M, Arnaud MJ, Kastenmayer P, et al. Meal effect on magnesium bioavailability from mineral water in healthy women. Am J Clin Nutr. 2002;75:65-71.

[19] Sabatier M, Grandvuillemin A, Kastenmayer P, et al. Influence of the consumption pattern of magnesium from magnesium-rich mineral water on magnesium bioavailability. Br J Nutr. 2011;106:331-334.

[20] Kiss SA, Forster T, Dongó Á. Absorption and effect of the magnesium content of a mineral water in the human body. J Am Coll Nutr. 2004;23:758S-762S.

[21] Verhas M, De La Guéronnière V, Grognet J-M, et al. Magnesium bioavailability from mineral water. A study in adult men. Eur J Clin Nutr. 2002;56:442-447.

[22] Nakamura E, Tai H, Uozumi Y, et al. Magnesium absorption from mineral water decreases with increasing quantities of magnesium per serving in rats. Nutr Res. 2012;32:59-65.

[23] Sheikh MS, Santa Ana CA, Nicar MJ, et al. Gastrointestinal absorption of calcium from milk and calcium salts. N Engl J Med. 1987;317:532-536.

[24] Rubenowitz E, Axelsson G, Rylander R. Magnesium in drinking water and body magnesium status measured using an oral loading test. Scand J Clin Lab Invest. 1998;58:423-428.

[25] Greupner T, Schneider I, Hahn A. Calcium bioavailability from mineral waters with different mineralization in comparison to milk and a supplement. JACN. 2017;36 (5):386-390.

[26] Walker AF, Marakis G, Christie S, et al. Mg citrate found more bioavailable than other $\mathrm{Mg}$ preparations in a randomised, double-blind study. Magnes Res. 2003;16:183-191.

[27] Fine KD, Santa ACA, Porter JL, et al. Intestinal absorption of magnesium from food and supplements. J Clin Invest. 1991;88:396.
[28] Tang NL, Cran YK, Hui E, et al. Application of urine magnesium/creatinine ratio as an indicator for insufficient magnesium intake. Clin Biochem. 2000;33:675678.

[29] Lindberg JS, Zobitz MM, Poindexter JR, et al. Magnesium bioavailability from magnesium citrate and magnesium oxide. J Am Coll Nutr. 1990;9:48-55.

[30] Mountokalakis TD. Effects of aging, chronic disease, and multiple supplements on magnesium requirements. Magnesium. 1987;6:5-11.

[31] Durlach J, Bac P, Durlach V, et al. Magnesium status and ageing: an update. Magnes Res. 1998;11:25-42.

[32] Marcelín-Jiménez G, Angeles-Moreno AP, Contreras-Zavala L, et al. A single-dose, three-period, six-sequence crossover study comparing the bioavailability of solution, suspension, and entericcoated tablets of magnesium valproate in healthy Mexican volunteers under fasting conditions. Clin Ther. 2009;31:2002-2011.

[33] Siener R, Jahnen A, Hesse A. Bioavailability of magnesium from different pharmaceutical formulations. Urol Res. 2011;39:123-127.

[34] Couzy F, Kastenmayer P, Vigo M, et al. Calcium bioavailability from a calcium- and sulfate-rich mineral water, compared with milk, in young adult women. Am J Clin Nutr. 1995;62:1239-1244.

[35] Brandolini M, Guéguen L, Boirie Y, et al. Higher calcium urinary loss induced by a calcium sulphate-rich mineral water intake than by milk in young women. $\mathrm{Br} \mathrm{J}$ Nutr. 2005;93:225.

[36] Gutenbrunner C, Gilsdorf K, Hildebrandt G. [The effect of mineral water containing calcium on supersaturation of urine with calcium oxalate]. Urol Ausg A. 1989;28:15-19. German. 